\title{
France thinks small for future satellite plans
}

Paris. Spurred on by the success of the experimental satellite Topex-Poseidon, France's National Centre for Space Studies (CNES) has announced plans to develop operational satellites that will be similar in design to Topex but four times smaller. But this ambitious programme, called Topex Poseidon Follow-On (TPFO), has yet to receive a promise of government funding.

Launched jointly with the National Aeronautics and Space Administration (NASA) in August 1992, Topex-Poseidon uses altimetric radar combined with a positioning system in order to measure, with great accuracy and almost instantaneously, average sea levels and the altitude of their oscillation.

Orbiting at a height of $1,300 \mathrm{~km}$, the satellite transmits about 500,000 measurements every ten days. Over a period of three years, Topex has allowed scientists to generate an enormous amount of data about both the topography of the ocean surface and the movements and evolution of ocean currents, as well as data about climate patterns.

One of the observations Topex has made possible is that the average sea level has risen by $4 \mathrm{~mm}$ a year since 1992 . This compares with an average rise of $1.8 \mathrm{~mm}$ a year since the start of the century, based on more conventional forms of measurement.

This rapid rise in sea level is probably the result of various phenomena such as the role of the oceans as a heat sink, the expansion of surface water in the oceans and the melting of glaciers and the polar ice-caps.

CNES officials are delighted with the results, and are keen to move on. "Our technological choice has been confirmed beyond our hopes," says Alain Rattier, head of Earth observation at CNES. "Now we want to do with a satellite of $450 \mathrm{~kg}$ the same as we did with Topex, with its 2 tonnes."

Speaking during a press conference in Paris last week to announce the new programme, André Lebeau, the president of CNES, talked of a series of such operational mini-satellites which, despite an estimated

- Such a move would conventionally have been made by the Foreign Ministry, and indicates an unusually strong protest by the Japanese government. Furthermore, Makiko Tanaka, head of the Science and Technology Agency, has sent a letter to French president, Jacques Chirac, urging him to reconsider the planned tests.

Until the appearance of the home page on the Web, however, there had not been a strong reaction from the Japanese public. For example, there has been no significant movement to boycott French goods as in some other countries - although one major department store has turned over price labels on French goods to discourage consumers from buying them.

The home page is therefore the first sign

\author{
IMAGE \\ UNAVAILABLE \\ FOR COPYRIGHT \\ REASONS
}

Big brother: French scientists are planning smaller versions of Topex-Poseidon (above).

development cost of a billion French francs (US\$206 million), would be relatively inexpensive while remaining highly reliable.

CNES has also produced a complementary proposal to develop a platform made up of mini-satellites - and provisionally named Proteus - that would be capable of adapta-

\section{MRC cuts funding of alpha-rated projects}

London. Britain's Medical Research Council (MRC) announced this week that the combined effects of financial pressures and high demand from biomedical researchers have made it necessary to reject 70 per cent of grant applications that had received an alpha grading during the review process.

The figures are based on the outcome of decisions over the award last month of $£ 35$ million (US\$56 million) in funding for new research programmes. They contrast strongly to the situation in several recent years when the council says it had been able "to fund all or virtually all long-term research proposals in these high quality categories".

As a result of this financial pressure, the MRC has had $£ 5$ million a year less to spend over the next four years than for the equivalent exercise last year. This situation has

of a significant grassroots movement of protest in Japan. The page declares "stop nuclear tests" and says "we strongly disapprove of the French government's decision to restart nuclear tests". The organizers say they kept the protest simple, and have, for example, not called for a boycott of French goods to encourage the maximum number of people to sign up. But individuals can register their views in an "opinions" corner on the home page.

The organizers will continue to run the home page after they deliver the first petition on 4 August, and will send subsequent updates to the French Embassy. The home page can be accessed at http://www.icepp.s.u-tokyo.ac.jp/ keshi/.

David Swinbanks
क्ष tion to various missions.

The main problem for TPFO is who will fund it. Cooperation with NASA, which had been so successful for Topex-Poseidon, is now in doubt. "NASA is very favourable to this idea, but there are problems with the US Congress," points out Rattier (see Nature 375, 9; 1995).

Congress will apparently have to choose between supporting Topex or the proposed Geosat Follow-On 2 (GFO-2), which is preferred by the US aerospace industry. "This programme will go ahead with or without the Americans," says Rattier.

Before that, however, the programme must be approved by the government, and then the two parliamentary bodies during discussion of the 1996 budget in the autumn. Even if space is still a protected area of French policy, budgetary restrictions are affecting all sectors of government spending. Financial support for TPFO is therefore far from guaranteed. But CNES officials are optimistic.

Catherine Tastemain

been partly created by pressure on the council to switch funding to strategic priorities identified through various government programmes, such as the Technology Foresight Exercise and the new ROPAs (Realizing Our Potential Awards) scheme.

"We understand the need for government financial stringency," the chairman of the MRC, Sir David Plaistow, said in a statement. But "no one should underestimate the damaging impact which this will have on the growing opportunities for high quality medical research work relevant to the health and prosperity of the United Kingdom".

MRC officials are careful to point out that the reduced funding available for highly-rated projects is the result of pressures that have built up over several years - similar difficulties are being report from other research councils - and are, they say, in no way linked to the recent decision to move responsibility for the council's into the Department of Trade and Industry.

Nevertheless, evidence that increased emphasis on strategic priorities may be resulting in reduced funding for investigator-initiated research grants is likely to fuel the continuing debate over the latter move and the government's efforts to harness the science base to the task of wealth creation.

Sir Arnold Wolfendale, for example, the former Astronomer Royal and currently president of the Institute of Physics, wrote in the Financial Times at the beginning of this week that such a move was "incompatible" with the desire, even voiced by industrial leaders, to maintain excellence in many scientific disciplines.

David Dickson 